\title{
Core Ethical Values of Character Education Based on Islamic Values in Islamic Boarding Schools
}

\author{
Ihin Solihin ${ }^{1}$, Aan Hasanah ${ }^{2}$, Hisny Fajrussalam ${ }^{3}$ \\ ${ }^{1}$ Universitas Islam Negeri Sunan Gunung Djati Bandung, Indonesia \\ 2Universitas Islam Negeri Sunan Gunung Djati Bandung, Indonesia \\ ${ }^{3}$ Universitas Pendidikan Indonesia, Indonesia
}

Corresponding Author: Ihin Solihin, solihinihin64@gmail.com*

\begin{tabular}{|c|c|}
\hline \multirow{3}{*}{$\begin{array}{l}\text { ARTICLE INFO } \\
\text { Article history: } \\
\text { Received } \\
\text { June 13, } 2020 \\
\text { Revised } \\
\text { July 15, } 2020 \\
\text { Accepted } \\
\text { July 18, } 2020\end{array}$} & ABSTRACT \\
\hline & $\begin{array}{l}\text { This research was motivated by the spread of radicalism ideology that's } \\
\text { carried out by leaders of some boarding schools (Islamic school of } \\
\text { Qur'anic studies), the degradation of society moral, and the immoral } \\
\text { behavior in education institutions. This research aims to investigate the } \\
\text { core ethical values of character education based on Islamic values in } \\
\text { Islamic boarding schools to facilitate the embedding of those values in } \\
\text { Indonesian society so that the radicalism ideology, moral degradation, } \\
\text { and immoral behavior can be eliminated. This research uses a qualitative } \\
\text { approach and method. The type of research is library research; data were } \\
\text { obtained from books, journals, and other relevant references. Then the } \\
\text { data were analyzed by using content analysis techniques. The result of } \\
\text { this research shows that the core ethical values of character education } \\
\text { based on Islamic values in Islamic boarding schools are divided into four } \\
\text { core teachings of Islamic studies, namely al-fiqh (fiqh), al-tauhid } \\
\text { (monotheism), al-tasawuf (Sufism), and al-akhlaq (moral). Values consist } \\
\text { in those four core teachings are cleanliness, health, neatness, faith, piety, } \\
\text { belief toward blessing (baraka), moderate, benignity, simplicity, self- } \\
\text { attitude of accepting and feeling sufficient for the results of his efforts } \\
\text { (qonaah), sincerity, humility, religious culture, respect for older people, } \\
\text { and hard work. }\end{array}$ \\
\hline & Keywords: Education Character, Islamic Values, Ethical Value \\
\hline How to cite & $\begin{array}{l}\text { Solihin. I., Hasanah, A., \& Fajrussalam, H. (2020). Core Ethical Value of } \\
\text { Character Education Based on Islamic Value in Islamic Boarding Schools. } \\
\text { IJoASER (International Journal on Advanced Science, Education, and Religion), 3(2). } \\
\text { 21-33. https://doi.org/10.33648/ijoaser.v3i2.51 }\end{array}$ \\
\hline nepage & https://ojs.staialfurqan.ac.id/IJoASER/ \\
\hline y & STAI Al-Furqan Makassar \\
\hline
\end{tabular}

\section{INTRODUCTION}

The character of a nation is a force in producing human resources, especially in the educational environment, because a high and advanced civilization can be built when the majority of the characters are strong, good, and positive. Contrarily a civilization will be destroyed when the character of the society is weak, bad, and negative. For this reason, a character is the main capital in building high-level civilizations. A society will produce an orderly and good social life system when it is honest, independent, cooperates, complies with regulations, can be trusted, responsible, and has a high work ethic.

Education needs to be encouraged to develop character, so that in the future nation will be able to build a more advanced and modern civilization. A modern 
civilization is at least created with four main pillars, namely the first, a strong parent of culture and religion. The second, an advanced education system. The third, a just economic system. The fourth, the advance of humanist science and technology (Hasanah, 2013).

Within character education, high integrated moral quality of human resources will be encouraged to be born, so that prosperity, independence and pleasure in life will be guaranteed, and split personality or multiple personalities does not appear anymore. The success of a nation in obtaining its goals is not only determined by the abundance of natural resources, but mostly determined by the quality of its human resources. A nation of a big country can be detected in terms of the quality or character of the nation and country, namely human beings themselves (Tafsir, 2004).

Indonesia, as a nation with the largest Muslim population in the world, is a big modal in instilling the values of character. That values are, of course, based on the values of Islamic teachings so that the Muslim community in Indonesia has an Islamic spirit. Islam development in Indonesia cannot be separated from the participation of Islamic boarding schools as the oldest Islamic education in Indonesia. We can even feel this role until now. Nevertheless, this is not without challenges. Some boarding schools teach education that is contrary to the values of this character. The author still remembers that a few years ago, the data compiled by the Indonesian National Counterterrorism Agency showed that 19 Islamic boarding schools in Indonesia spread radicalism in their teachings (Armenia, 2016). Even this radicalism is still a real and serious threat until these days (Biliocta, 2019). On the other hand, the morality of people in Indonesia does not yet reflect an absolutely Islamic society. The latest data obtained by the Ministry of Communication and Information shows that there are still high public complaints about negative content in Indonesia, even that pornography ranks first as the most content that is complained by Indonesian people (Kominfo, 2020). Even recent research says that physical and psychological abuse often occurs in an educational environment (Agus et al., 2020).

Islamic boarding schools have an essential role to be able to solve this problem by conducting serious guidance for students and the surrounding community to propagate the character education based on Islamic values so that Indonesian people hold fast to these values. Furthermore, ethical values in Islamic boarding schools are combined with the school curriculums. Researches on character education at Islamic boarding school have been widely provided out, for example, a research conducted by (Nofiaturrahmah, 2017; Yahya, 2016). However, both kind of research not yet concerned with the discussion of the core ethical values of character education in Islamic boarding schools. The research conducted by them only focuses on the character education model. Therefore, this article offers a study of character education with a different perspective, namely by exploring the core ethical values of character education based on Islamic values in Islamic boarding schools. Although the author realizes that he will not fully explain this study, at least he has tried to discuss it.

\section{METHODS}

This research uses a qualitative approach and method. This type of research is library research using iductive-deductive analysis as well as a comparison of literature (Moser \& Korstjen, 2018; O'Dwyer \& Bernauer, 2013), which means that data are obtained from various books, journals and relevant references. This type of research is a literature study or literature study that contains theories that are relevant to research problems. This section reviews the concepts and theories used based on the available 
literature, especially from articles published in various scientific journals. A literature study serves to build concepts or theories that form the basis of study in research. After all the data has been collected, the next step is to analyze the data so that a conclusion is drawn (Arikunto, 2010). Literature study or literature can be interpreted as a series of activities relating to the method of collecting library data, reading and recording and processing research material (Mulyatingingsih \& Nuryanto, 2014). The method of collecting data in this study is documentation, which is collecting data and information from some relevant literature. This means that the researcher examines and/or explores several journals, books, and documents (both printed and electronic) as well as other sources of data and/or information deemed relevant to research or studies. The data analysis technique used is content analysis, which is a technique used to analyze and understand the text.

Content analysis is a research technique for making replicable and valid inferences from texts (or other meaningful matter) to the contexts of their use. As a technique, content analysis involves specialized procedures. It is learnable and divorceable from the personal authority of the researcher. As a research technique, the content analysis provides new insights, increases a researcher's understanding of particular phenomena, or informs practical actions (Krippendorff, 2018). The stages to be carried out in this study are the first is determining the theme. At this stage, researchers conducted more observations of data in the form of documents. Look for topics of interest and in this study topic of interest to researchers are finding a framework for a lifetime education the second is formulating the Problem. This stage is the reason why a topic is decided to be tested. This is done by researchers to formulate the problem with the chosen theme. The third is Collect data and determine research methods. Namely conducting theoretical studies related to the research topic. Literature sources can be obtained from books, journals, magazines, news, research results (thesis, thesis, and dissertation) and other relevant sources. The fourth is Analyze and compile the data findings. The last is draw conclusions. This stage is the answer to the research objectives which are at the conceptual/theoretical level. Researchers regularly arrange the data obtained so that they can conclude from the data that has been collected

\section{RESULT AND DISCUSSION}

\section{Concept of Character Education}

Education is an effort to advance the character, mind, and physical child so that it is in harmony with nature and society (Dewantara, n.d.). According to Marimba, education is guidance or training consciously by educators on the physical and spiritual development of students towards the formation of a complete personality (Marimba, 1989). Whereas Albertus defines education as a process of cultural internalization into individuals and society to become civilized (Albertus, 2010).

In Article 1 verse (1) of the Law Number 20 of 2003 which is concerning the National Education System, it is stated that education is a conscious and planned effort to create a learning atmosphere and process. So that students actively develop their potential to have religious-spiritual strength, self-control, personality, intelligence, noble character, and the skills needed by him/herself, society, nation and state (Undang-Undang Republik Indonesia No. 20 Tahun 2003 Tentang Sisdiknas, 2003; UndangUndang Republik Indonesia Tahun 2005 Tentang Guru Dan Dosen, 2005).

The word character comes from the character of the French word, and the character of the Latin word, which means "a sign, a distinctive quality". The Greek 
character word is "charassein" which is defined as "giving meaning or carving (Fajrussalam \& Hasanah, 2018; Sulasmono et al., 2017). Character according to Poerwadarminta in Syarbini (2012) means character, mental characteristics, moral or demeanour that distinguishes a person from others. The figuration of character cannot be segregated from the role of the teacher, because everything that is done by the teacher can influence the character of learners. The character is formed from three interrelated parts, namely moral knowledge, moral feelings, and moral behaviour (Lickona, 2008). Thus, a character is a steady, sturdy and special nature inherent in a person that makes him/her behave and act spontaneously without requiring first thought, and cannot be affected by circumstances (Syarbini, 2012).

Character is the unity of mindset (logo), conscience (ethos), and attitude (pato). Character is the values of human behaviour related to God, human beings, the environment, nationality and him/herself that is shown in thoughts, attitudes, feelings, words, actions based on religious norms, law, manners, cultures and customs. Character education is the inculcation of noble values to students to realize knowledge, awareness or wills, and actions to implement these values (Widiantari, 2017).

A crucial point of the educational task is to build the character of students. Character is an internal standard that is implemented in various self-quality forms. Self-character is based on values and ways of thinking based on these values and manifests in behaviour. The Indonesia Heritage Foundation expresses like this; love for Allah SWT and the universe together with its contents, responsibility, discipline and independence, honesty, respect and courtesy, compassion, caring and cooperation, confident, creative, hard work and unyielding, justice and leadership, kind and humble and tolerant, love peace and unity. American Character Counts identify the characters that are pillars: trustworthiness, respect and attention, responsibility, honesty, caring, citizenship, sincerity, courage, perseverance and integrity.

In essence, any form of character that is formulated must remain based on universal values. Therefore, education that develops character is a kind of education that can help strengthen ethical attitudes, morals and responsibilities by giving love to students, showing and working on good character (Syarbini, 2012). Character education is a process of activities carried out with all the power and effort consciously and planned to direct students. Character education is a process of activities that leads to the improvement of the education quality and the development of harmony that always teaches, guides, and fosters every human to have intellectual competence, character, and interesting skills.

The values of character education that be able to internalized are as follows: religious, nationalist, intelligent, responsibility, discipline, independent, honest, wise, respectful, polite, generous, helpful, mutual assistant, confident, hard-working, tough, creative, leadership, democratic, humble, tolerance, solidarity and care for others (Hasanah, 2013). Albertus explained that character education is where there is a place for individual freedom to live values that are considered good, noble, and worth fighting for as guidelines for behaving for personal life related to himself, others and God (Albertus, 2010).

Thomas Lickona defines the character as the nature of a person in response to a moral situation that is revealed in concrete actions through good behaviour, honest, responsible, respectful of others and other noble characters. Lickona emphasizes three things in educating character; knowing, loving, and acting the good. According to him, the success of character education begins with a good understanding of character, love it, and the implementation of good character (Lickona, 2009). Character education aims 
to improve the quality of implementation and educational outcomes that lead to the achievement of the formation of character and noble character of students in full, integrated and balanced (Kesuma \& dkk, 2011).

In essence, character education aims to form a strong nation, competitive, noble, moral, tolerant, cooperation, patriotic-spirited soul, developing dynamically, oriented to science and technology, all of which are imbued with faith and devotion to God Almighty One based on Pancasila (Gunawan, 2012). Thus, character education is everything teachers do that can influence the character of students. Teachers help in developing the character of students; this includes role models for teacher behaviour, the way teachers talk or deliver material, how teachers tolerate and other related matters.

Character education has the same essence and meaning as moral education. The goal is to shape the child's personality so that he becomes a good human being, a good citizen and citizen. Therefore, the nature of character education in the context of education in Indonesia is the education of values, namely the education of noble values that originate from Indonesian culture itself, to foster the personality of the younger generation (Hasanah, 2013).

\section{The Relationship of Islam with Education as Core Ethical Values of Characters}

Character education can ideally build the public character of the Indonesian people towards high civilization if character education can be properly and correctly implemented in the schools, families and communities. To realize noble morals in everyone's life, the cultivation of noble morals becomes a necessary thing. In schools or educational institutions, this cultural effort is carried out through giving moral education, moral education, ethics education, or character education (Hasanah, 2011; Hidayat, 2017).

Islam is a conceptual framework in character education, the concept of man as a creature that has an element of physical, spiritual, passion, and the concept of man as nature which emphasizes the potential for religious and inclined to the truth. With these two concepts, the developed character education is character education in the perspective of the development of potential religious person. By using the moral perspective in character education, Islam functions as a core ethical value as a source of individual behaviour (Hasanah, 2013). There are several core ethics which are derived as values that can be taught through the educational methodology. When we discuss values in character education, they must be taught at home, at school and in the community. These values can be agreed upon and generally applied in the context of character education as good values are mutually agreed upon and need to be taught to shape the character of the children and all community. These values have a directive nature because they lead to good behaviour, to be responsible and to the goals of national education. The following picture can facilitate the understanding of Islam as core ethical values in character education: 
Figure 1. Schema of Islam as a Framework for the Concept of Core Ethical Values

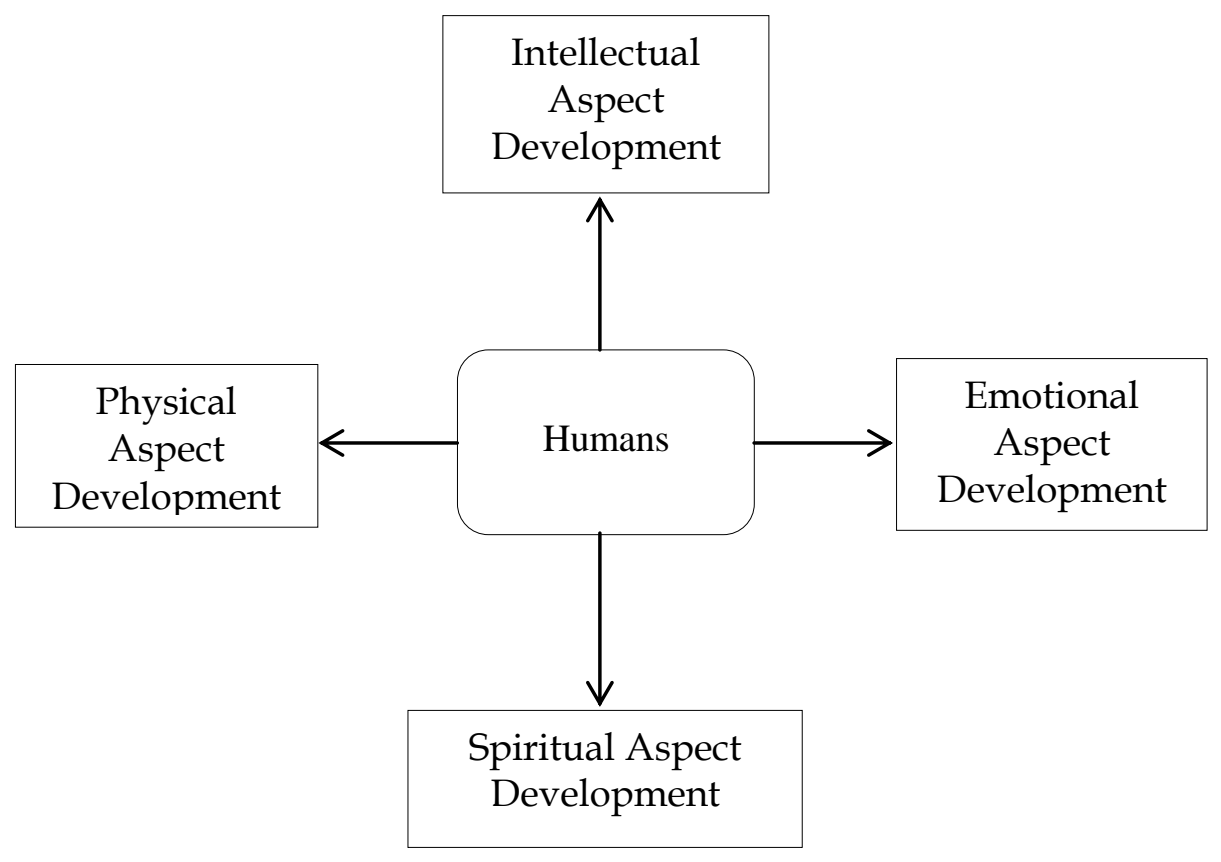

As the basis for character education, Islam used as a conceptual framework for the development of character education. In this case, the human role is as subject and object in character education. Human consists of the physical aspects of health, cleanliness and tidiness. The spiritual aspect related to the development of the diversity of learners, namely faith and piety. Emotional aspects related to the development of students' affective aspects, namely caring, creative, and empathy. Intellectual aspects related to the intelligence of students. These aspects are developed in Islamic education (Hasanah, 2013).

Therefore, it is answered that Islam is very appropriate to be used as core ethical values of character education because it has universal and absolute values maintained by its Creator, valid for all time and serves as a way of life for humans. Anyone who believe it will not lose in the afterlife later.

\section{Core Ethical Values of Character Education Based on Islamic Values in Islamic Boarding School}

The term character is not very popular in the boarding school environment. Another term used to mention the same definition as a character is moral (al-akhlaq). Therefore, some experts agree to align the term of character with moral (al-akhlaq) as one definition. This is not without reason. Education in Islamic boarding schools, with the tradition of the yellow book, often uses the term of moral (al-akhlaq) to mention a person's attitude and personality. Some of these books are Akhlaq li al-Banin, Akhlaq li al-Banat, Ta'lim al-Muta'allim, Adab al-Alim wa al-Muta'allim and many more. However, such difference in terms does not eliminate the essence that character education has been taught in Islamic boarding schools through the yellow book tradition.

Meanwhile, Islam, as a religion carried in the boarding school environment, is a religion that is rich in values. These values then grow and develop in Islamic boarding schools so that they became characteristic of the core ethical values of character education in Islamic boarding schools. Based on the explanation of the relationship 
between Islam and Education as Core Ethical Character Values in the previous subchapter, the core ethical values of character education based on Islamic values in Islamic boarding schools can be drawn from various aspects in human beings. For more details can be seen in the following picture:

Figure 2. Core Ethical Values of Character Education Based on Islamic Values in Islamic Boarding School

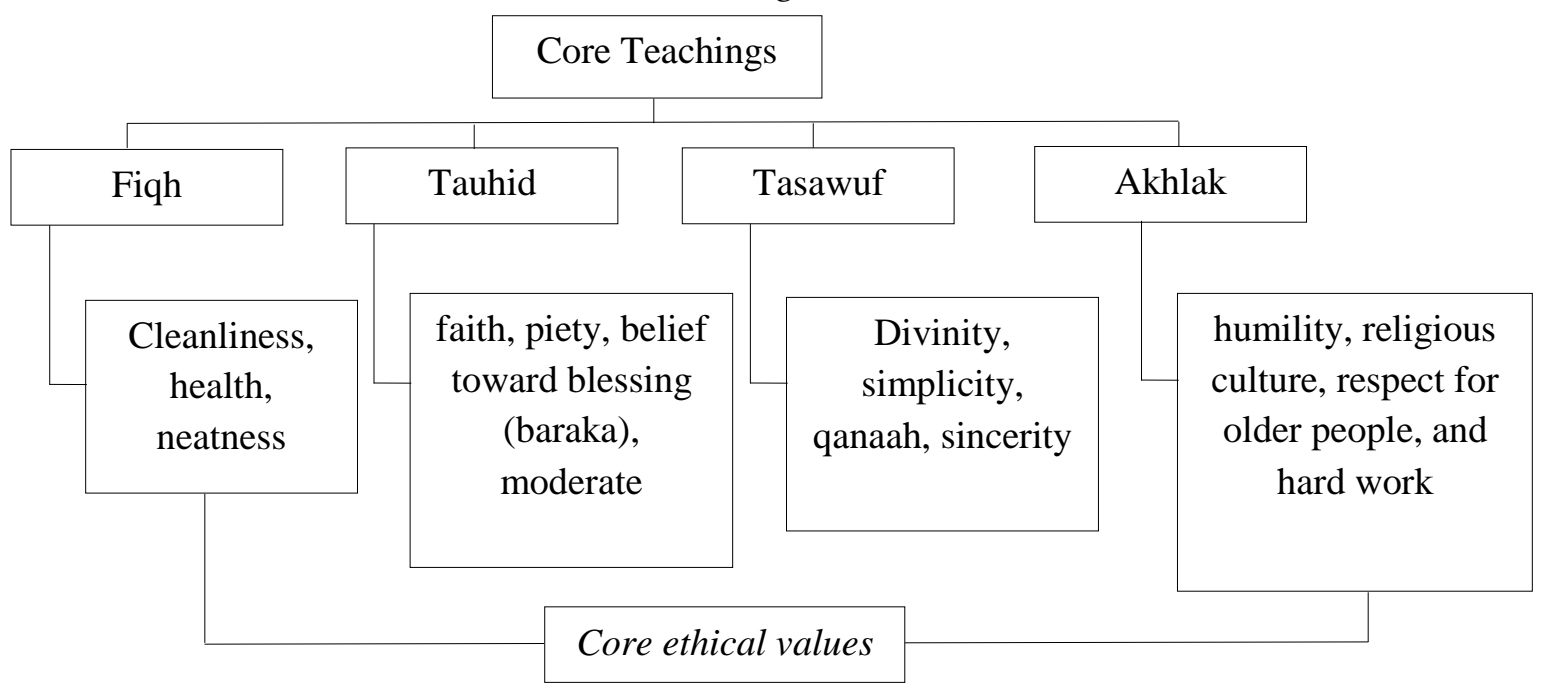

From Figure 2. we can see that the core ethical values of character education based on Islamic values in Islamic boarding schools are divided into 4 core teachings, namely fiqh, monotheism (tauhid), Sufism (tasawuf), and moral (akhlaq).

First, core ethical value derived from fiqh teachings is cleanliness. At the boarding school, there is a very well-known saying that cleanliness is part of faith. Students at Islamic boarding schools are taught to always maintain personal hygiene and boarding schools environment through cleaning assignments (Muhtarom, 2014). Maintaining cleanliness is part of caring for the environment, and this is an implementation of the concept of character education based on environmental maintenance (Yusuf et al., 2019). Students are also taught to maintain health by eating halal and clean food, because consuming illicit (haram) food and drinks is a prohibition in Islam. Currently, there is a lot of health empowerment in Islamic boarding schools to improve clean and healthy living behaviours. To realize that, the things that need to be done are 1) Procurement; namely awareness by providing information and skills to boarding school dwellers about the basics, benefits, and urgency of clean and healthy behaviour in the boarding school environment; 2) Assistance; namely through assistance to Islamic boarding schools in forming internal boarding school health institutions; 3) Management training and formation of healthy student cadres; namely providing knowledge about the management and development of work relationships for internal boarding school health institutions, and conducting training for healthy student cadres as an investment in the sustainability of the boarding school internal health agency program that has been built. Partner participation is carried out starting from the preparation stage to the management of the internal boarding school health institution. Partner participation is evaluated in each activity, so it is hoped that at the end of the activity, the sustainability of the program can continue (Rif'ah, 2019). In addition, tidiness is also a concern in the boarding school environment. Many boarding 
schools apply white uniforms used by students in the learning process and activities in the boarding school environment.

Second, monotheism (tauhid). From this core teaching, students are given an understanding to always practice the six pillars of faith. Understanding of this teaching is often taught through the learning activities of books that contain faith discussions such as Jauhar al-Tauhid, Kifayah al-Awam and Sanusiyah. By understanding and practising the pillars of faith, students will be accustomed to devote to Allah Almighty by doing all His commands and avoiding His prohibitions. The students' trust in the existence of a Creator, Allah Almighty, also creates confidence in the existence of blessing (barakah). In a literature mentioned that the definition of barakah is the increase of good in someone. Students in Islamic boarding schools often scrambled to kiss the hands of their teachers (Kiai, Ulama) and cleared their sandals that were scattered in front of the mosque to pursue this blessing. In fact, this attitude is an attempt of students to become a better person. Barakah is also perceived as local values as a personal moral symbol of the Kiai/Ulama (the term for Islamic teachers), both as a central and spiritual figure because the Kiai/Ulama is believed to have a closeness to Allah so that the Kiai/Ulama is perceived as Auliya 'Allah (those who have predicate as the guardians/lovers of Allah). The interpretation of barakah is represented by increasing the value of goodness and being able to become positive energy in developing the self-concept by imitating the Kiai's//Ulama's personality as a moral role model, as well as a way for the students to gain useful knowledge after he returns to their hometown (Fauzi, 2017).

Students are also taught to be moderate. This attitude aims to guide students to live flexible in society. Pesantren, as the oldest Islamic educational institution in Indonesia with various challenges, has the responsibility to teach moderate Islam that is tolerant, loves peace and respects fellow human beings both Muslim or non-Muslim (Aini, 2018). The result shows that the formation of moderate attitudes in Islamic boarding schools can be seen from daily, weekly, monthly, and yearly activities. These student activities can form an attitude of love for God and all of His creation, honesty, wisdom, respect and courtesy, helpfulness, tolerance, the spirit of nationalism and nationality, love of the motherland, love of peace. These attitudes are trained in the habits of students to achieve appropriate competencies accompanied by strong desire (Fitriyah \& Muhammada, 2019).

Third, the teachings brought by Islamic boarding schools are Sufism (tasawuf). The implementation of the concept of Sufism in daily life in Islamic boarding schools can be seen from the generous attitude of students. Students are taught to always help their friends who are struggling, both in the form of material and services. The attitude of generosity in Islamic boarding schools is also often seen when students work together to help with the construction of Islamic boarding schools. Students in Islamic boarding schools are also accustomed to living as simply as possible. The simplicity of a student can be seen from the clothes used, namely the caps, Koko clothes, gloves and sandals. This simplicity can also be seen from the habits of students who consume very ordinary food in one large enough plate/container and eat it together. What is interesting is that the simplicity of the facilities owned by Islamic boarding schools does not discourage students from achieving success (Sun'iyah, 2018). Also, students are taught to be qona'ah. Qona'ah is accepting for what Allah gives. Students must not complain about what He has given. Therefore, whatever is given by Allah must be grateful, because in one of His verses Allah says: 


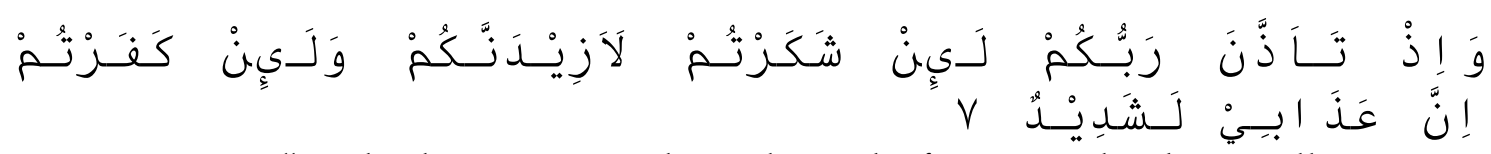

It means: "And when your Lord proclaimed: If ye give thanks, I will give you more; but if ye are thankless, lo! My punishment is dire." (Q.S. Abraham: 7)

A research states that understanding qona'ah values can increase high levels of self-esteem [31]. Therefore, students in Islamic boarding schools are strived to continue to have this attitude. In carrying out daily activities, students are also taught to have a trustworthy character, which is to do all activities always because they face the pleasure of Allah Almighty, whether it as worship, study, eat, drink or so on.

Fourth, the core ethical values of character education in Islamic boarding schools are derived from moral teachings (akhlaq). Humility (tawadlu) as part of moral teachings in Islamic boarding schools is an inseparable part in a student. Arrogant attitude and feeling yourself better than others are an attitude that must be avoided. This can be seen from the words and attitudes of a student. Then, at the Islamic boarding school students are also taught to always carry out activities that are cultural boarding schools, for example, tahlilan (praying in congregation aimed at people who have died), marhaba (reading the history of the birth of the Prophet Muhammad and reading invocation), bahtsul masail (discussion or debate on various problems of the Islamic religion) and so on. These activities are nothing but to foster a love of culture when students enter the society. In addition, students are also taught to respect elders. We can see the attitude of students when meeting with a Kiai/Ulama or just walking with him. Attitudes towards the Kiai / Ulama, such as walking behind him and not catching up with him, lowering his eyes and lowering his voice when talking to him, are one part of the example of respect for older people. Another thing that can be seen is hard work. Students are accustomed to always learning, worshipping and doing activities in the boarding school environment on time. So that in full-day students are invited to be accustomed to hard work to become perfect human beings. The result of the study shows that character building through the full-day program can run more effectively because teacher development of students is more intensive. Also, the inculcation of Islamic boarding school values can provide provisions for students, such as worshipping parents, living simply and frugally, discipline, and so on (Niam, 2019).

\section{Implementation of Core Ethical Values of Islamic Values Based Education in Islamic Boarding Schools}

Generally, in Islamic boarding schools, the implementation of value/character development can be divided into four pillars. Those are teaching and learning activities, daily activities in the form of educational unit culture, co-curricular and extra-curricular activities, and daily activities at home and the community.

a. In teaching and learning activities in Islamic boarding schools, the development of values/characters is carried out using an integrated approach in all studies of the yellow book (embedded approach), specifically for the study of moral books, because its mission is to develop values and attitudes. Then the development of value/character must be the main focus that can use a variety of strategies/methods of value education (value/character education).

b. Within the boarding school education environment, it is conditioned so that the physical and socio-cultural environment allows students along with other residents to get accustomed to building daily activities that reflect the manifestation of values /character. 
c. In co-curricular activities, learning activities outside the classroom that are directly related to a material from a subject, or extra-curricular activities, educational unit activities that are general and not directly related to a subject, such as Youth Red Cross (Palang Merah Remaja) activities, it is necessary to develop a process of habituation and reinforcement in the context of developing student values /character.

d. In the family and community environment, an effort is made to strengthen the parents/guardians and community leaders to conduct noble character. This behaviour is developed in Islamic boarding schools and is expected to become a daily activity at home and in their respective communities.

In implementing Islamic values, as core ethical values character education in Islamic boarding schools, we can start with 3S. First, start with yourself. As an individual of a group or individual of oneself, each person must be able to build awareness and strengthen the noble values in him/herself first, before teaching the values to others. For example, a Kiai/Ulama wants to teach the nature of discipline to his citizens, so he must set an example for his students. At least a Kiai/Ulama greet students when they come to boarding schools. When a Kiai/Ulama wants to deliver the importance of the spirit of learning, before it is delivered to his students, the Kiai/Ulama must have a high enthusiasm when teaching his students. When some parents want to instil honesty to their children, they must give examples in advance about the attitudes and honest words. Second, start from a small thing. The big result starts from the small thing. Great attitudes and actions that are considered not necessary must be realized to have high value for the development of character. For example, saying an apology, saying thank you, congratulating, greeting, praying when going to start and ending learning, throwing trash in its place, dressing neatly, cleaning culture or smiling. All of these things have important values about how to respect others. Besides, getting used to praying in congregation, carrying out tasks on time and other activities can develop according to the circumstances at the time. Third, starting from now. There are no age and time restrictions in character formation. Humans are thinking beings who can process to be better and better anytime, as the Arabic proverb says, "Man Jadda Wajadda", anyone who is serious will succeed.

The main finding of this research is that the core ethical values of character education based on Islamic values in Islamic boarding schools are divided into 4 core teachings, namely fiqh, monotheism (tauhid), Sufism (tasawuf), and moral (akhlaq). The different of the main finding in this research to other main finding previous research that the previous research only focus on the discussion of ethical values based on Islamic values in the general without mentioning more specifically.

The implications of this research can be applied scientifically and practically. In the scientific world, this research can be used as a reference in the development of Islamic boarding school. In the practical realm, the implementation of this research can be used as material to improve the understanding and practice of students in Islamic boarding schools based on Islamic values in order to archieve the noble ideals of the Islamic religion.

\section{CONCLUSIONS}

Character education is a process of activities carried out with all the power and conscious and planned efforts to direct students to develop ethical attitudes, morals and responsibilities by giving love to students, showing and working on good character. Islam, in character education, is used as a framework, concepts/references 
for developing the potential common in humans. Humans, as subjects as well as objects in Islamic education, have a high chance to develop all their competencies, because humans have been given a complete set of devices of the body which consist of physical aspects, namely health, cleanliness, neatness. Religious aspects related to the development of students' variety, namely faith and piety. Emotional aspects related to the development of students' affective aspects, namely caring, creative, and empathy. Intellectual aspects related to the intelligence of students. The core ethical values of character education based on Islamic values in Islamic boarding schools that can be found are cleanliness, health, neatness, faith, piety, belief toward blessing (baraka), moderate, benignity, simplicity, self-attitude of accepting and feeling sufficient for the results of his efforts (qonaah), sincerity, humility, religious culture, respect for older people, and hard work. All of these values are taught in the four core teachings of Islamic boarding schools, namely al-fiqh (fiqh), al-tauhid (monotheism), al-tasawuf (Sufism), and al-akhlaq (moral). Therefore, Islam is very appropriate to be used as the core ethical values of character education because it has universal values, absolute and maintained by its Creator which is valid for all time, and functions as a way of life for humans. Anyone who believe it will not lose in the afterlife later.

\section{ACKNOWLEDGEMENTS}

The author say thanks to the IJoASER (International Journal on Advanced Science, Education, and Religion) that have provided the opportunity to publish this paper. The author also thanks Prof. Aan Hasanah, M.Ed. and Hisny Fajrussalam, M.Pd. who has provided guidance and suggestion so that this paper can be completed.

\section{AUTHOR CONTRIBUTION STATEMENTS}

The author had participated in the research and approved the final version of the manuskript.

\section{REFERENCES}

Agus, A. A., Qalbi, N., Hanafie, K., \& Muhammadong, M. (2020). Implementation of Education Character to Overcome Students' Harvestion. IJoASER: International Journal on Advanced Science, Education, and Religion, 3(1), 1-10. https://doi.org/10.33648/ijoaser.v3i1.41

Arikunto, S. (2010). Prosedur penelitian. Google Scholar

Aini, A. Q. (2018). Islam Moderat di Pesantren: Sistem Pendidikan, Tantangan, dan Prospeknya. Edukasia Islamika, 3(2), 218-233. https://doi.org/10.28918/jei.v3i2.1689

Albertus, D. K. (2010). Pendidikan Karakter Strategi Mendidik Anak di Zaman Global. Grasindo. Google Scholar

Armenia, R. (2016, February 4). BNPT: 19 Pesantren Terindikasi Ajarkan Radikalisme. CNN Indonesia. https://www.cnnindonesia.com/nasional/20160203201841-20108711/bnpt-19-pesantren-terindikasi-ajarkan-radikalisme

Biliocta, Y. (2019, Oktober). Radikalisme Dinilai Masih Jadi Ancaman Nyata di Indonesia. Merdeka.Com. https://www.merdeka.com/peristiwa/radikalismedinilai-masih-jadi-ancaman-nyata-di-indonesia.html

Dewantara, K. H. (n.d.). Pendidikan. Majelis Luhur Persatuan Taman Siswa. Google Scholar 
Fajrussalam, H., \& Hasanah, A. (2018). Core Ethical Values of Character Education Based on Sundanese Culture Value. IJECA (International Journal of Education and Curriculum Application), 1(3), 15-22. https:/ / doi.org/10.31764/ijeca.v1i3.2126

Fauzi, A. (2017). Persepsi Barakah di Pondok Pesantren Zainul Hasan Genggong: Studi Interaksionalisme Simbolik. Al-Tahrir: Jurnal Pemikiran Islam, 17(1), 105-132. https:/ / doi.org/10.21154/altahrir.v17i1.848

Fitriyah, N., \& Muhammada. (2019). Pembentukan Karakter Ideologi Moderat di Pesantren Ngalah Purwosari Pasuruan. Al-Murabbi: Jurnal Pendidikan Agama Islam, 4(2), 303-320. https:/ / doi.org/10.35891/amb.v4i2.1555

Gunawan, H. (2012). Pendidikan Karakter Konsep dan Implementasi. Alfabeta.

Hasanah, A. (2011, Oktober). Pendidikan Karakter Berbasis Islam (Studi Atas Konsep dan Konstribusinya dalam Pembentukan Karakter Bangsa) [Sinopsis Disertasi]. Sidang Tertutup, UIN SGD Bandung.

Hasanah, A. (2013a). Pendidikan Karakter Berperspektif Islam. Insan Komunika.

Hasanah, A. (2013b). Pendidikan Karakter Berperspektif Islam. Insan Komunika.

Hidayat, R. (2017). Core Ethical Values Pendidikan Karakter Berbasis Nilai-Nilai Islam. Sabilarrasyad: Jurnal Pendidikan Dan Ilmu Kependidikan, 2(2), 1-21.Google Scholar

Kesuma, D., \& dkk. (2011). Pendidikan Karakter Kajian Teori dan Praktik di Sekolah. Remaja Rosdakarya. Google Scholar

Krippendorff, K. (2018). Content analysis: An introduction to its methodology. Sage publications. Google Scholar

Kominfo. (2020, January 8). Siaran Pers No. 04/HM/KOMINFO/01/2020 Rabu, 08 Januari 2020 Tentang Kominfo Terima Lebih Dari 430 Ribu Aduan Konten Negatif Sepanjang $2019 . \quad$ https://kominfo.go.id/content/detail/23705/siaran-pers-no04hmkominfo012020-tentang-kominfo-terima-lebih-dari-430-ribu-aduankonten-negatif-sepanjang-2019/0/siaran_pers

Lickona, T. (2009). Educating for Character: How Our School Can Teach Respect and Responsibility. Bamtam Books. Google Scholar

Lickona, T. (2008). Pendidikan Karakter Panduan Mendidik Siswa Menjadi Pintar dan Baik. Nusa Media. Google Scholar

Marimba, D. (1989). Pengantar Filsafat Pendidikan Islam. Al-Ma'arif.

Moser, A., \& Korstjen, I. (2018). Series: Practical Guidance to Qualitative Research. Part 3: Sampling, Data Collection and Analysis. European Journal of General Practice, 24(1), 9-18. https:/ / doi.org/10.1080/13814788.2017.1375091

Muhtarom, A. (2014). Pembinaan Kesadaran Lingkungan Hidup di Pondok Pesantren: Studi Kasus di Pondok Pesantren Al-Mansur Darunnajah 3 Kabupaten Serang. Ibda': Jurnal Kebudayaan Islam, 12(2), 225-240. https:// doi.org/0.24090/ibda.v12i2.448

Niam, Z. W. (2019). Membina Karakter Anak Melalui Program Full Day School Berbasis Nilai-Nilai Kepesantrenan (Studi Kasus di Madrasah Ibtidaiyah Nurul Ummah Kotagede Yogyakarta). Belajea: Jurnal Pendidikan Islam, 4(1), 19-34. https://doi.org/10.29240/belajea.v4i1.696

Nofiaturrahmah, F. (2017). Metode Pendidikan Karakter di Pondok Pesantren. Jurnal Pendidikan Agama Islam, 11(2), 201-216. https:/ / doi.org/10.14421/jpai.2014.11204

O'Dwyer, L. M., \& Bernauer, J. A. (2013). Quantitative Research for the Qualitative Researcher. SAGE Publications. Google Scholar 
Rif'ah, E. N. (2019). Pemberdayaan Pusat Kesehatan Pesantren (Poskestren) Untuk Meningkatkan Perilaku Hidup Bersih Dan Sehat. Warta Pengabdian, 13(3), 96105. https:// doi.org/10.19184/wrtp.v13i3.11862

Sulasmono, P., Ekosiswoyo, R., \& Widodo, J. (2017). The Integration of Local Cultural Wisdom Values in Building The Character Education of Students. International Journal of Education and Research, 5(6), 151-162. Google Scholar

Sun'iyah, S. L. (2018). Optimalisasi Kesederhanaan Sarana Pendidikan di Pondok Pesantren Salafiyyah dalam Membentuk Karakter Islami. Dar El-Ilmi: Jurnal Studi Keagamaan, Pendidikan Dan Humaniora, 5(2), 115-135. Google Scholar

Syarbini, A. (2012). Buku Pintar Pendidikan Karakter: Panduan Lengkap Mendidik Karakter Anak di Sekolah, Madrasah, dan Rumah. As@-Prima Pustaka.

Tafsir, A. (2004). Filsafat Pendidikan Akal dan Hati. Remaja Rosdakarya.

Undang-undang Republik Indonesia No. 20 Tahun 2003 tentang Sisdiknas. (2003).

Undang-undang Republik Indonesia Tahun 2005 tentang Guru dan Dosen. (2005).

Widiantari, D. (2017). Core Ethical Values Pendidikan Karakter (Berbasis Falsafah Negara). Misykat: Jurnal-Ilmu al-Quran, Hadits, Syariah, Tarbiyah, 2(2), 21-38. https:// doi.org/10.33511/misykat.v2n2.21-38

Yahya, S. (2016). Model Pendidikan Karakter di Pondok Pesantren (Studi Kasus di Pondok Modern Al-Syaikh Abdul Wahid, Kota Baubau Sulawesi Tenggara) [Tesis, Universitas Islam Negeri Maulana Malik Ibrahim]. Google Scholar

Yusuf, M., Mardan, M., \& Nahdiyah, N. (2019). Natural Environment Character Education Based on Islam. IJoASER: International Journal on Advanced Science, Education, and Religion, 2(3), 1-12. https://doi.org/10.33648/ijoaser.v2i3.35 